\title{
9 \\ China and arms control: a learning process
}

\author{
Gary Klintworth
}

Any discussion of China's approach to arms control policy, in terms of whether or not it has acted responsibly, needs to be placed in context. And the proper context is Sino-US relations and US attitudes towards China as a great power. It is only the United States that has vigorously scrutinised China's arms control behaviour. It is only the United States that has accused China of not complying with its arms control commitments and it is only the United States that has the capacity to make life difficult for China on arms control issues. Looking at the material on China and arms control, most of it comes from the US government or The Washington Post. And indeed, it is only the United States, with its national technical means of intelligence (that is, high resolution satellites) and its intelligence network in China that has the ability to tick or cross the boxes on China's compliance with arms control regimes like the Missile Technology Control Regime (MTCR). Sometimes the United States gets it right and sometimes, relying on circumstantial evidence, it gets it wrong.

As a general observation, it is safe to say that China has moved from a position of disinterest and opposition in the 1950s and 1960 s to a strong commitment to arms control and nonproliferation of weapons of mass destruction (WMD) by the 1990s. 
Why did China make this shift? The simple answer to the question, and I believe the best one, is that China wants a safer world, with a reduced risk of tension and conflict so that it can restrain its defence budget and concentrate scarce resources on domestic economic reform, reconstruction and modernisation. That goal requires global peace and stability. Of course, there may be a longterm strategic imperative behind China's modernisation, with arms control merely an interim ploy pending China's attainment of superpower status. China, after all, is pressing ahead with the acquisition of modern Russian weapons and military technology at a quickening pace.'

But for the moment I am not inclined to the view that China's interest in arms control stems solely from concerns about realpolitik, defined in terms of a concern about China's global image and a desire to rein in the power of the United States and the former Soviet Union. ${ }^{2}$

Michael Swaine and Alastair lain Johnston suggest that China is 'acutely sensitive to its international image as a peaceful leader of less-developed countries and a strong advocate of completeWMD disarmament'. They canvass a possible shift by China towards acceptance of the value of a common security approach to arms control but conclude that China's approach is dictated by the realpolitik interests of a relatively weak state. ${ }^{3}$ There may be some truth in this but I think China was and is interested in the same common security values as the United States, and that means getting along with the United States.

China therefore seeks to avoid the threat of sanctions and the embarrassment of adverse publicity about proliferation deals with states regarded by the United States as so-called rogue or outlaw states. It wants to avoid fuelling the already combustible anti-China lobby in the US Congress because that would mean a possible loss of US technology and cooperation. This would have seriously adverse consequences for China's survival, development and modernisation. China wants to preserve diplomatic and commercial relations with the United States at almost any cost (leaving aside 
the question of Taiwan). That means restricting the export of strategic missile andWMD technologies to states not well-regarded by the United States and Israel, such as Iran, Iraq, Syria, Saudi Arabia, Algeria, Libya, North Korea and, more recently, Pakistan.

Robert J. Einhorn, Deputy Assistant Secretary of State for Nonproliferation has acknowledged China's willingness to engage with the United States on nonproliferation 'frequently and at various levels'. He judged that China had become a leading participant in such forums as the Conference on Disarmament (CD) and that the Chinese appreciated, like everybody else, that Beijing's national security interests were not served by the spread of dangerous military capabilities. ${ }^{4}$

\section{China's record}

Until 1964, China had no real policy on nuclear weapons and arms control. It was rather more concerned about building a credible nuclear capability. It considered attempts to limit testing and proliferation as discriminatory but, after its first atom bomb test on 16 October 1964, it did propose, and has proposed ever since, a no-first use treaty and support for regional nuclear weaponsfree zones. ${ }^{5}$ China started to participate actively in the global arms control process with the commencement in 1978 of an open door foreign policy and engagement with the rest of the world. China joined the Geneva Conference on Disarmament in 1980. It stopped atmospheric tests in the same year. It joined the International Atomic Energy Agency (IAEA) in 1984. It put forward working papers and proposals on nuclear disarmament. In later years, China signed the Inhuman Weapons Convention, the Antarctic Treaty, the Outer Space Treaty, the Biological Weapons Convention (BWC), the Seabed Treaty, the Non-Proliferation Treaty (NPT), the South Pacific and Latin America Nuclear-Free Zone Treaties, and the Chemical Weapons Convention (CWC) and the Comprehensive Test Ban Treaty (CTBT). All these treaties were related to controls on the use and deployment of nuclear weapons, nuclear proliferation and nuclear testing. 


\section{Comprehensive Test Ban Treaty}

China conducted its first nuclear test in 1964. Fourteen years later in 1980, it was committed to the values of a nuclear arms control regime. It joined the Conference on Disarmament in Geneva. It announced on 21 March 1986 that it would cease nuclear tests in the atmosphere (although it actually stopped in October 1980). It participated in the negotiations for a CTBT from the beginning (January 1994) and pursued a CTBT that was fair, reasonable and verifiable, with universal adherence and unlimited duration. China's representatives played an active role negotiating at the CTBT conference table. They presented many working papers and suggestions regarding the draft text and dealt with a series of critical issues in the Preamble, Basic Obligations, Organisations, Verification and Entry into Force sections of the treaty. ${ }^{6}$ China announced a moratorium on all nuclear tests as of 30 July 1996. It signed the CTBT on 24 September 1996 despite reservations about the absence of provisions on no-first use of nuclear weapons, a timetable for Russia and the United States to dismantle their huge nuclear arsenals, unsatisfactory procedures relating to inspections and the need to permit tests for peaceful nuclear purposes. ${ }^{7}$

China also claims that by signing the CTBT it paid the highest price because technically, with just 46 tests (compared to over 1000 conducted by the US, 800 by Russia and 200 by France), it had not completed all the tests it needed to ensure the reliability and safety of its arsenal. In other words, the technical gap between China and the other nuclear powers has been frozen by the CTBT, but even so, China was prepared to sign the CTBT in the interests of global arms control and its responsibilities as a nuclear power. ${ }^{8}$

According to a PLA officer, China made 'the great sacrifice' in the interests of 'preserving world peace' and eliminating the threat of nuclear war. ${ }^{9}$ That is, China claimed it was acting for reasons of what Alastair lain Johnston calls idealpolitik although, in his view, China actually signed up primarily for reasons of realpolitik-that is, its image as a responsible peace-loving global citizen. ${ }^{10}$ 


\section{Nuclear Non-proliferation Treaty}

China ratified the NPT on 9 March 1992 and helped secure an indefinite extension to the Treaty in May 1995. China may have signed the NPT primarily for reasons of realpolitik just like the United States, Britain and the former Soviet Union but it signed it nonetheless, the fourth nuclear weapon state to do so, and five months ahead of France. Zachary Davis suggests that the reasons were to correct China's poor international standing after the Tiananmen massacre in June 1989, to access Western nuclear technology, to avoid the loss of MFN (Most Favoured Nation) treatment in the United States, to avoid being left out of the NPT club, and only lastly to reduce the risk of nuclear proliferation."

In April 1996, China became the $18^{\text {th }}$ country to ratify the IAEA's International Convention on Nuclear Safety.

China's publicly stated position has consistently been that it does not engage in nuclear proliferation activities and will not advocate or encourage nuclear proliferation and does not engage in developing, or assisting other countries to develop, nuclear weapons.

China claims that it has consistently approached the question of the transfer of sensitive materials and military equipment with the utmost gravity and that it supports the NPT goals of preventing the spread of nuclear weapons and accelerating nuclear disarmament. Beijing claims that is has always stood for the complete prohibition and thorough destruction of nuclear weapons, pursuing a policy of not supporting, encouraging or engaging in the proliferation of nuclear weapons and not assisting any other country in the development of such weapons. China, however, maintains that these aims should not prevent other countries, especially the developing ones, from being able to make peaceful use of nuclear energy. ${ }^{12}$

As a weapon state party to the NPT, China is prohibited from helping a non-weapon state develop nuclear weapons. Moreover, it must make any nuclear-related transfers to non-nuclear weapon states subject to the safeguards of the IAEA. 
China has consistently denied that it has ever helped Pakistan develop nuclear weapons. Although an allegation was made in 1983 that China had given Pakistan sufficient highly enriched uranium for two bombs, there is as yet no evidence that China supplied either plutonium or highly enriched plutonium to Pakistan or indeed to any other non-nuclear weapon state. ${ }^{13}$ Pakistan has imported nuclear technology from China but has never acquired any nuclear weapons technology from China, according to the Pakistani Foreign Office. ${ }^{14}$

China claims it wants neither tension nor an arms race in South Asia. That is logical and sensible for China. It has pursued the same goals as the United States on the non-proliferation of nuclear weapons in South Asia. It condemned the May 1998 nuclear tests conducted by India and Pakistan and urged both states to stop their nuclear testing, to abandon plans to arm themselves with nuclear weapons, to sign the CTBT and the NPT unconditionally and accept the IAEA full-scope safeguards. ${ }^{15}$

China has worked closely with the United States to help defuse tension in South Asia. On 27 June 1998, Presidents Jiang Zemin and Bill Clinton issued a joint statement reaffirming that their common aim was to prevent the export of equipment, materials or technology that could in any way assist programs in India or Pakistan for nuclear weapons or for ballistic missiles capable of delivering such weapons. ${ }^{16}$ According to US Deputy Assistant Secretary of State Susan Shirk, China actually led the UN Security Council-with US help and support-to coordinate efforts within the Security Council to devise ways to prevent a nuclear arms race in South Asia. ${ }^{17}$

China has turned down requests from Libya for nuclear technology.

China is alleged to have at least contributed to North Korea's nuclear weapons research program, but there is no evidence to support this claim. ${ }^{18}$ China has a shared interest with the United States in ensuring the Korean peninsula, and by extension Japan, remains non-nuclear. Indeed, Beijing put a lot of time and effort into urging North Korea to ratify the NPT's full-scope safeguards agreement in 1992. In the last decade, moreover, China has resisted North Korean requests for military assistance and has played a 
constructive role in finding solutions and restraining North Korea from pursuing the nuclear and missile option. China's key role in helping the United States convince North Korea to freeze and eventually dismantle its nuclear program has been acknowledged by senior US officials.

China has attracted criticism from the United States because it supplied a nuclear reactor to Algeria and has since cooperated with Algeria on nuclear energy research. Both China and Algeria have denied any collaboration on nuclear weapons. But US intelligence experts alleged that the reactor was larger than would be required for routine nuclear research and US Senate Foreign Relations Subcommittee Chairman Joseph Biden claimed it was evidence that China was becoming a rogue elephant. ${ }^{19}$ It would appear, however, that what China is doing in Algeria complies with the inspection requirements of the IAEA - the project was approved by the IAEA and was subject to supervision and inspection by IAEA experts during its construction and test operation. Furthermore, China persuaded Algeria to place its nuclear facilities under IAEA safeguards in $1991 . .^{20}$

In the case of Iran, China argued that what it was doing was consistent with the NPT in that it was helping Iran safeguard a uranium conversion facility. The United States, however, was concerned that Iran could divert material from the conversion facility into a clandestine weapons-related centrifuge enrichment program with nuclear weapons potential. ${ }^{21}$ In the end, however, in October 1995, China withdrew authority for the sale of two $300,000 \mathrm{~kW}$ nuclear reactors to Iran after talks between then US Secretary of State Warren Christopher and then Chinese Foreign Minister Qian Qichen.2 China also cancelled the sale to Iran of a uranium conversion facility and turned down an Iranian request for a heavy water moderated research reactor. That is, China complied with US prodding to stop helping Iran with its nuclear program, notwithstanding China's energy-derived interest in building up goodwill in Tehran and elsewhere in the Middle East. Admittedly, the offset was billions of dollars of US nuclear reactors, equipment and technology for peaceful nuclear programs that China might not otherwise have been licensed to receive. ${ }^{23}$ 


\section{Biological Weapons Convention (BWC)}

China ratified the Biological Weapons Convention in November 1984 and there has been no suggestion of a breach, even by the US Congress, despite growing concerns expressed by the US Director of Central Intelligence for Nonproliferation. ${ }^{24}$ In 1998, China agreed to work with the United States to negotiate an enforcement protocol for the BWC. ${ }^{25}$

\section{Landmines}

In 1982, China signed the 1980 United Nations (UN) Convention on the Prohibition of Certain Indiscriminate Conventional Weapons with its associated Protocol II on landmines. China took an active part in the amendment of the Landmine Protocol and, in 1996, signed a revised version of the Protocol prohibiting the transfer of landmines that are undetectable and that do not contain self-destructive devices. Like the United States, however, China is not in favour of a complete ban on landmines. Beijing regards them as indispensable defensive weapons for a country with long land borders and 'an uncertain security environment'. Thus, according to China's former Disarmament Ambassador in Geneva, Sha Zukang, China reserves the right to use landmines on its own territory until alternative means of defence are found. ${ }^{26}$

\section{Chemical Weapons Convention (CWC)}

China signed the CWC in January 1993 and ratified it in December 1996 despite reservations about provisions for challenge inspections. ${ }^{27}$ But China has a mature chemical warfare capability and has produced and weaponised a wide variety of agents according to the US Department of Defense. ${ }^{28}$

China is alleged to have at least contributed to North Korea's chemical weapons research program. However, there is no public available evidence to support this claim or any firm evidence that China has breached its undertakings under the CWC. 
In July 1993, there were accusations that China was supplying Iran with chemicals. Then, US intelligence sources accused China of selling Iran thiodiglycol and thionyl chloride-chemical precursors for making mustard and nerve gases. In August 1993, the US Navy-with the agreement of the Chinese government-searched the Yin $\mathrm{He}$, a Chinese container ship in the Gulf of Hormuz only to find nothing to support the allegation. According to Robert J. Einhorn, Deputy Assistant Secretary of State for Nonproliferation, Department of State, US intelligence was good and the Chinese were just lucky not to be caught out. ${ }^{29}$ Nonetheless, the US State Department expressed appreciation for China's cooperative and forthright assistance in resolving the dispute in the interests of nonproliferation of goods and technology that might be used in WMD. ${ }^{30}$

In May 1997, the United States imposed sanctions on seven Chinese chemical companies for allegedly assisting Iran's chemical weapons program. ${ }^{31}$

According to Gary Milhollin, Director of the Wisconsin Project on Nuclear Arms Control, US officials were of the view that China had been exporting poison gas ingredients, equipment and technology to Iran since at least 1992 and that such exports, including entire factories, were continuing. ${ }^{32}$ However, the chemicals involved were dual use items with civilian applications, and China held up the supply of raw materials to an alleged chemical weapons factory. ${ }^{33}$

Significantly, China subsequently agreed to strengthen controls over the export of dual-use chemicals and it expanded the list of chemical precursors that will be under those controls. ${ }^{34}$ But it is not easy for China to audit the thousands of enterprises and laboratories that might be engaged in the manufacture of dualuse chemicals.

According to the US State Department, citing the positive Chinese response to a proposed sale by a Chinese entity of a chemical-anhydrous hydrogen fluoride - to the Isfahan Nuclear Research Centre in Iran, "the US is firmly of the view that there has been a sea-change in Chinese policies and practices on 
nonproliferation and that China is moving towards the kind of relationship that advances and protects the security of the United States, its interests and its allies'. ${ }^{35}$

\section{Strategic arms reduction}

On strategic arms reduction, China's position is fairly well known. According to China's White Paper, China: arms control and disarmament, the United States and Russia must take the lead in 'drastically reducing their stockpiles of all types of nuclear weapons and means of delivery' and commit themselves to a treaty of nofirst use, a formula that suits China's relatively weak strategic circumstances. Only after the United States and Russia reduced their stockpiles by 50 per cent, would China participate in discussions on strategic arms reductions. ${ }^{36}$ Given the overwhelming superiority of the US strategic arsenal (6000 to China's 200-300), it is difficult to argue that China's case does not have some merit.

In the United States, however, this is regarded as 'free riding'that is, China prefers measures that advantage China's relatively weak position and gives least support to measures that impose constraints on China. ${ }^{37}$ In my view, this is simply a case of China practising some realpolitik.

\section{Missiles}

During the Iran-Iraq war in 1981-85, China sold both sides over US $\$ 4$ billion worth of arms, such as tanks and tactical missiles such as the Silkworm, (a slow, old-fashioned anti-ship cruise missile). But China did not sell Scud missiles to Iran and Iraq, despite claims to the contrary (the Scuds came from the USSR). In 1987, China sold 36 now obsolete Dong Fang 3 or CSS-2 Intermediate Range Ballistic Missiles (IRBMs, range $3000 \mathrm{~km}$ ) to Saudi Arabia for US $\$ 3$ billion, a deal that may been the carrot for Saudi Arabia to switch diplomatic relations from Taipei to Beijing in 1990.

China may have helped North Korea reverse engineer Soviet Scud missiles in the late 1970s, but there is no evidence that China helped North Korea develop its Nodong or Taepodong missile. $^{38}$ 
In 1989, China agreed to sell $48 \mathrm{M}-9$ missiles (range $600 \mathrm{~km}$ ) to Syria.This deal was cancelled by China in January 1992 after lengthy negotiations with the United States involving the threat of commercial sanctions relating to computers and satellites and possibly offers of assistance from Israel to fill critical gaps in China's defence technology.

In March 1992, China reached a bilateral agreement with the United States to abide by the guidelines and parameters of the Missile Technology Control Regime (MTCR), established by the United States in 1987). MTCR, it should be noted is a voluntary agreement, has no international legal authority, and China is not a member. China also agreed to the five-power Arms Control in the Middle East (ACME) forum limiting arms sales to the Middle East.

The MTCR was upgraded in July 1992 to deny the export of any system suspected of being used as a delivery system for WMD. Category II also requires case by case evaluations for exporting complete unmanned delivery systems that do not meet the Category I threshold $(300 \mathrm{~km})$ but which can fly more than 300 $\mathrm{km}$ with a minimal payload (such as biological weapons), as well as dual use components, materials and other commodities. These expanded guidelines were designed to counter Chinese moves to operate on the fringe and circumvent the original MTCR guidelines through piecemeal technology transfer. In October 1994, China signed an agreement with the United States to comply with the 1987 version of the MTCR, that is, to not export complete missiles that are inherently capable of reaching a range of 300 kilometres with a payload of 500 kilograms.

There is no evidence that China has violated its pledge not to export such missiles. On 21 November 2001 , China declared that it would not assist other countries in any way to develop ballistic missiles capable of delivering nuclear weapons, a move welcomed by the Australian government. ${ }^{39}$ But so far China has not agreed to stop exporting the missile technologies or shorter range systems armed with conventional warheads. MTCR, moreover, still leaves open the door for China to claim it has received assurances from the recipient that the equipment or technology supplied will not be used to develop a proscribed missile system. 
China also interprets the MTCR differently to the United States. The United States claims the 'inherent capability' of a missile should be used to see if it is covered by MTCR guidelines. That is, regardless of its payload, the question is whether the missile can reach 300 kilometres if its payload is adjusted. China's view is that if the missile is below the 300 kilometre threshold, it is not caught by MTCR guidelines. Thus, when China sold CSS-8 missiles (range 150 kilometres) to Iran it argued that they were not covered by the MTCR, and that China had signed the contract with Iran in 1988 which was prior to its agreement to comply with the MTCR.

A similar process took place with regard to US concerns about China selling some C-80I and C-802 anti-ship missiles to Iran. The $\mathrm{C}-80 \mathrm{I}$ has a range of 50 kilometre. The $\mathrm{C}-802$ has a range of 120 kilometre. Both are subsonic. They are not the kind of missile that ought to be covered by MTCR. Despite this, US Congressman Christopher Cox, Chairman of House Republican Policy Committee complained that US forces stationed in the Gulf-the 15,000 men of the US Fifth Fleet-were within range of the Chinese missiles and that the United States therefore, should apply the Gore-McCain Iran-Iraq Arms Nonproliferation Act of 1992. This Act requires the President to sanction nations that transfer 'destabilizing numbers and types' of advanced weapons to outlaw nations like Iran. ${ }^{40}$

Even though China was not threatened with sanctions over the missiles, it nonetheless promised to stop supplying additional antiship cruise missiles, including those under contract, or the technology to achieve over-the-horizon capability or indigenous production. ${ }^{41}$

So far, China has stuck to its general MTCR Category I undertakings although many reports to the contrary have appeared in The Washington Post.

The United States would like China to become a full member of MTCR and tighten its missile technology controls for example; with regard to Pakistan..$^{42}$ I note however that Swaine and Johnston argue that the United States does not want China to become a member of MTCR because it would have to share sensitive intelligence information and membership would exempt China from sanctions. ${ }^{43}$ 


\section{Pakistan}

Pakistan is something of a special case for China and is often mentioned as one of the exceptions to China's promises to abide by its arms control commitments. For China, Pakistan balances India's quest for hegemony in South Asia and, bearing in mind China's Muslim region of Xinjiang, Pakistan is a useful ally for China to have on side as insurance against Islamic fundamentalism in Central and Inner Asia.

Pakistan has been one of the largest markets for Chinese conventional arms and equipment such as fighter aircraft and tanks. China is Pakistan's most reliable and extensive source of conventional arms. ${ }^{44}$ China therefore has a historical and strategic interest in helping Pakistan, an old friend and tacit ally since China's war with India in 1962. For China, a strong Pakistan presents a potential second front to India vis-à-vis the latter's rivalry with China. So, while China advocates nuclear and missile nonproliferation, it is under some obligation to help Pakistan if and when India appears to be getting the upper hand, for example, with the development of its Agni and Privthi missiles. ${ }^{45}$

It would not be surprising, therefore, to find that China has been the source of Pakistan's missile technology even though China has not provided Pakistan with actual missiles. In 1988, China contracted to supply Pakistan with up to $40 \mathrm{M}-1 /$ missiles, with delivery to commence in 1991. According to the Chinese, the 290 kilometre range of the M-II meant it was not covered by the MTCR whereas the United States claims the M- II has a range of 309 kilometres and is therefore caught by MTCR. ${ }^{46}$

According to US intelligence sources, China shipped launchers and key components of the $\mathrm{M}-\mathrm{I} / \mathrm{I}$ missile to Pakistan in November 1992. Following pressure from the United States, however, the deal either lapsed or another solution was found because there was and is no evidence that completed missiles were ever shipped to or even assembled in Pakistan, notwithstanding allegations that US satellite intelligence had spotted M-1/ missiles in crates at a Pakistani airbase at Sargodha. ${ }^{47}$ 
There is an assumption that Pakistan used the M-II technology or components to build the Hatf-III but it remains an assumption because nobody has seen a Hatf-III. Nor is there any conclusive evidence to support the allegation that China helped Pakistan build an $\mathrm{M}-\mathrm{I}$ I production facility in Rawalpindi. ${ }^{48}$ However, according to Senate Foreign Relations Committee Chairman, Jesse Helms, the CIA's National Intelligence Estimate on Military Threats to the US was 'absolutely clear that there is zero doubt about China having transferred M-1/ missiles to Pakistan'. ${ }^{9}$

China reportedly refused to sell Medium Range Ballistic Missiles (MRBMs) to Pakistan. On the other hand, Pakistan's Shaheen I Short Range Ballistic Missile (SRBM) looks remarkably like China's M-9 or Dong Fang DF-15 (range 600 kilometres). It has the same nose shape, the same fins, the same length and diameter and no country makes a similar missile. Oddly, however, despite all the fuss about the M-II, the United States has not yet expressed complaints about the Shaheen I.

Meanwhile, Pakistan has in fact been looking at North Korea's Nodong missile technology to build its Ghauri I or Hatf-V (range 1500 kilometres) to match India's Agni SRBM (range 2000 kilometres), possibly because China was not forthcoming with the technology or parts.

China has also helped Pakistan build a complete $300,000 \mathrm{~kW}$ nuclear power station at Chashma, 260 kilometres from Islamabad under a 1992 agreement. China provided the assistance on the basis that it would be a use of nuclear power for peaceful purposes. It claims that the transfer is subject to IAEA safeguards. Beijing claims that any suggestion that it is helping Pakistan develop nuclear weapons is groundless. ${ }^{50}$ The equipment was made in Shanghai and included high and low pressure heaters, condensers, water tanks, and other non-nuclear devices. ${ }^{51}$

China has also been helping Pakistan develop nuclear technology at the Khan Research Laboratories (KRL) in Kahuta. In 1995, the United States objected to China's sale of 5000 ring magnets to KRL (ring magnets are used to make enriched fuel for nuclear bombs as well as civilian-use fuel rods). The ring magnets were sold to Pakistan by a company in Shanghai, the China Nuclear 
Energy Industry Corporation (CNEIC). The Chinese government pleaded that it did not know about the sale until the United States raised the matter and that the ring magnets were not part of the Nuclear Suppliers Group's trigger list, that they were not prohibited and, in any case, they had civilian uses. Since it upset the United States so much, however, the Chinese National Nuclear Corporation undertook to prevent any further exports to unsafeguarded facilities and introduced even stronger controls on the Nuclear Suppliers Group dual list as well as the Zangger Committee's trigger list. China also agreed to consult with the United States in future on other export control arrangements for nuclear related technologies.

China accommodated the United States because, it has been argued that under a 1994 US law-the Nuclear Proliferation Prevention Act-the United States can deny bank loans, credit and insurance to any country that wilfully aids states to acquire unsafeguarded nuclear material. If the United States decided that China had 'wilfully' helped Pakistan, companies like Westinghouse and Bechtel might suffer. But the truth of the matter is that the central government in Beijing probably had no idea that a Chinese company in Shanghai was selling ring magnets to nuclear facilities in Pakistan.

\section{Weak export controls in China}

In an effort to placate the United States, China claimed that it established a Military Sales Leading Group in 1989 to oversee arms exports, chaired by Army chief, General Liu Huaqing, with representatives from the General Staff Department (GSD), the Central Military Commission (CMC) and the Foreign Ministry. In April 1992, it claimed to have created several monitoring groups, such as the State Military Exports Administration Commission, to stop unauthorised arms sales.

If China did supply countries like Pakistan and Iran with missiles, components and technology, the problem may have arisen in part at least because China does not have an effective national control system. Thus, even when Beijing is willing to exercise restraint, its 
ability to do so is inadequate, especially in the area of chemical export controls. ${ }^{52}$ According to another observer, China had in effect two export control systems, one civilian and one military, with a gap between the two that sometimes allows unauthorised items to slip through. ${ }^{53}$

In some cases, the State Council and the Ministry of Foreign Affairs may not know what a distant branch of China's huge military-industrial complex is doing or selling. In fact, it would appear that the US intelligence community has a better grip than China's central bureaucracy on what China's provincial industries are or are not exporting in terms of chemical precursors and nuclear and missile technology, or related bank account transactions.

Generally, the Chinese Ministry of Foreign Affairs, the Ministry of Foreign Economic Relations and Trade and the Chinese National Nuclear Corporation have made genuine efforts to implement a responsibleWMD and missile-related export control system. They understand the broader principles of non-proliferation and have sought to ensure China's compliance with its arms control obligations. The Foreign Ministry recognises compliance is an important and sensitive issue in Sino-US relations and that preserving that relationship is more important than earning a small amount of cash, important as that might be to some chemical factory in Shenzhen or Shanghai.

Bureaucrats in Beijing, however, do not have a list of every company producing dual-use technologies like ring magnets or dual-use WMD components in the chemical industry. There were until recently something like 10,000 military-owned enterprises such as the China Poly Group and the China Precision Machinery Import and Export Corporation. They have an estimated turnover of US\$10-18 billion and function more or less autonomously. Industries might sell equipment without consulting the central government. In the case of the ring magnets-very unsophisticated devices-they were treated under China's export control system as routine general commercial goods.

In November 1995, China's State Council released a White Paper titled China: arms control and disarmament. It stated that arms exports must be used for the legitimate defence of recipients, 
not for aggression, and must not harm regional peace and security. The White Paper stated that any corporation or individual who transferred weapons or military equipment without examination and approval by the government would be strictly dealt with according to law.

As it turned out, the person responsible for the sale of the ring magnets to Pakistan was dismissed. ${ }^{54}$ Of course, it might not have been irrelevant that a company like China Great Wall Industrial Corporation, at the forefront of China's space industry, stood to lose billions of dollars in business and, more importantly, access to critical US technologies if sanctions were imposed, all for the sake of ring magnets worth a mere US\$70,000.55

On the other hand, some conservative PLA leaders might feel China needs to placate Pakistan and the oil-rich Muslim states in the Middle East and Central Asia. In the view of this constituency, if the United States misbehaves in areas of great sensitivity to China, such as selling F-16s and missile defence related military technology to Taiwan, despite a commitment (in Beijing's view) under the Taiwan Relations Act not to do so, they see no reason why China should not reciprocate in kind in areas of great sensitivity to the United States, that is, to Muslim states in the Middle East or old friends of China's like Pakistan. ${ }^{56}$

This attitude-and I am speculating - might explain the CNEIC's subsequent sale and installation at unsafeguarded nuclear facilities in Pakistan of a special industrial furnace and high-tech diagnostic equipment 'with military applications' (the furnace could be a vacuum or skull furnace used to melt plutonium and uranium for nuclear bomb cores and titanium for missile nose cones and other critical missile parts). According to a top secret CIA memorandum dated 14 September 1996, paperwork had been falsified to disguise the final destination of the technology but senior Chinese leaders probably approved the illicit sale. ${ }^{57}$ The US State Department made its concerns known to Beijing but, according to another report, US State Department spokesman Nicholas Burns stated that he was 'absolutely confident' that China had not violated the commitment it had made on II May 1996. ${ }^{58}$ 
A similar problem arose in March 2001 after US allegations that Chinese firms were helping Iraq improve its air defences by installing fibre-optic cables, contrary to UN-imposed sanctions. China's Foreign Minister Tang Jiaxuan strenuously stated the allegations were unfounded. He claimed that the Chinese government was 'very serious, very strict and always responsible in implementing UN resolutions on Iraq' and that Chinese businesses were prohibited from engaging in trade or other economic activities in Iraq that were contrary to UN Security Council resolutions. ${ }^{59}$

\section{The black view of China}

The suggestion of bureaucratic ineptitude as an explanation for China's problematic record is not accepted by many influential people in Washington. While it is generally true that some sales of Chinese technology and products associated with WMD to Iran and Pakistan were undertaken by semi-autonomous entities without Beijing's approval, there was 'convincing evidence' that other deals were negotiated and executed with Beijing's knowledge and tacit approval, according to Mitchel B. Wallerstein, a Deputy Assistant Secretary of Defense for Counterproliferation Policy in the US Department of Defense. ${ }^{60}$

In 1997, in testimony to the US Congress, Gary Milhollin, Director of the Wisconsin Project on Nuclear Arms Control, alleged that China was not fulfilling its 1994 commitment to comply with MTCR and, citing US officials, he alleged that China was continuing to export missiles and missile technology to Pakistan, including assistance with an M-1I missile production plant. He also alleged, citing US officials, that China had been exporting poison gas ingredients, equipment and technology to Iran since at least 1992 and that such exports, including entire factories in 1996, were continuing. ${ }^{61}$ He claimed that the ring-magnet sale to Pakistan was no accident and represented China's ongoing support for Pakistan's nuclear weapons program, beginning in 1980. He claimed that, because the ring magnets were made specifically to go into centrifuges that make enriched uranium for nuclear weapons and because they were sold to Pakistan by the China National Nuclear Corporation, an arm of the Chinese government, it amounted to 
a violation of the NPT. Milhollin made similar allegations with regard to China's nuclear assistance to Iran-Chinese inputs directly assisted Iran's nuclear weapons program. According to Milhollin, China was a rogue state and the United States would not be able 'to stop a rogue state from being a rogue state by treating him like a non-rogue'. ${ }^{62}$

Likewise, the Director of US Central Intelligence, George Tenet, said in his report to Congress in June 1997, that China was the most significant supplier of WMD-related goods and technology to foreign countries. He alleged in January 1998, that 'there is no question that China has contributed to WMD advances in Pakistan and Iran'.63

In a similar vein, the Chairman of the US Senate Foreign Relations Committee, Jesse Helms, and Senate Intelligence Committee Chairman, Richard Shelby, alleged that China was and is an irresponsible Great Power and that it had a 'long record of proliferation of the most dangerous weapons technologiesfrequently in violation of earlier commitments and international norms and obligations-combined with a history of denial, deception, evasion and lying about these activities'. They cited the ClA's Non-Proliferation Centre as stating in June 1996 that China was 'the most significant supplier of weapons of mass destructionrelated goods and technology to foreign countries and the primary source of nuclear-related equipment and technology to Pakistan and a key supplier to Iran'. ${ }^{64}$

The Cox Report, commissioned by the US Congress in June 1998 (Select Committee on US National Security and Military/ Commercial Concerns with the People's Republic of China) was released on 25 May 1999. Three hundred pages were regarded as too sensitive for release. The Cox Report capped a crescendo of allegations about China's record on arms control and alleged that China was one of the leading proliferators of complete ballistic missile systems and missile components in the world and had possibly proliferated the world's most sophisticated nuclear weapons technology to nations hostile to the United States. China, according to the report, had sold complete ballistic missiles to Saudi Arabia and Pakistan, and components to a number of 
countries, including Pakistan. The report alleged that China had proliferated military technology to Iran, Pakistan and North Korea, and that China had not accepted the revised MTCR guidelines. It alleged that China was providing assistance to the missile programs of Iran (guidance components, solid propellant missile technology, the CSS-8 surface-to-surface missile with a range of I 50 kilometres, and the C-802 anti-ship cruise missile with a range of 120 kilometres), Pakistan (M-1/ missile launchers and the facilities to produce $M-\|$ missiles, assistance with uranium enrichment, ring magnets and other technologies that could assist a nuclear weapons program), Saudi Arabia (CSS-2 missiles) and North Korea (unspecified weapons and military related programs) as well as other proliferation activities that could not be publicly disclosed. ${ }^{65}$

\section{The US Administration: yes or no?}

There are obvious policy differences on China's proliferation record in the US Administration. On the one hand, there is the Cox Report, above, which US Energy Secretary Bill Richardson, said read like 'a suspense novel' and tended to sensationalise what were mostly allegations, not proven facts. And, despite allegations about Chinese assistance to Iran's nuclear weapons program, President Clinton certified on 12 January 1998 that he was completely convinced by China's assurances on nuclear nonproliferation, whereas just two weeks later George Tenet, the Director of Central Intelligence, testified to Congress that China's relations with some proliferant countries like Iran and Pakistan was longstanding and deep and that China had not promised to stop nuclear cooperation with either country. ${ }^{66}$ According to Gary Milhollin, US engagement with China on the nonproliferation of missile and chemicals had 'run out of gas' with the US State Department choosing not to apply sanctions to China and that, therefore, sanctions as a deterrent or punishment, as intended by the US Congress, were not working. ${ }^{67}$

These differences are confusing for anybody trying to work out the extent to which China is being responsible or irresponsible on nonproliferation of WMD. 


\section{Clinton Administration report card}

Nonetheless, it is reasonably clear that China is fairly sensitive to US strategic sensitivities, at least whenever it is caught out.

China wants to preserve access to US markets and technology and it is concerned about the anti-China mood in Congress. China's US policy is to seek common ground, find areas of cooperation and avoid confrontation. China has thus been increasingly willing to scrutinise and restrain nuclear exports and cooperation and to address US concerns promptly and seriously.

One would expect the former US Secretary of State, Madeleine Albright to be well-informed by her Department. Speaking in 1997, she said it was 'evident in the last several years that China had 'systematically joined a number of nonproliferation regimes-the NPT, the CTBT, the CWC and the Zangger Committee, and it was generally moving within the regime of control of weapons of mass destruction'. She said that the United States had received assurances that China would not engage in any new nuclear cooperation with Iran and that the existing cooperation-two projects in particular-would end. ${ }^{68}$ Specifically, China had

- promulgated for the first time strict national regulations to control exports of nuclear material, equipment and technology

- issued a State Council directive controlling export of dual use items with potential nuclear use

- joined the Zangger Committee, an international group which coordinates international suppliers efforts to control nuclear exports

- agreed not to provide assistance to unsafeguarded nuclear facilities, including through personnel and scientific exchanges

- provided assurances addressing US concerns about nuclear cooperation with Iran

- tightened controls over the export of chemicals that could be used in chemical weapons programs

- agreed to take steps to address US concerns about the provision of advanced conventional weapons to Iran which threaten maritime activities and regional stability. ${ }^{69}$ 
The United States, which regards nonproliferation as one of its highest priorities, had the following goals in its engagement with China.

- To terminate Chinese assistance to Pakistan's unsafeguarded nuclear facilities and nuclear explosive program.

- To curtail Chinese cooperation with Iran's unsafeguarded nuclear program.

- To establish an effective Chinese nuclear and nuclear-related dual-use export control system.

- To obtain Chinese participation in multilateral nuclear export control efforts.

Significantly, in February 1998, US Deputy Assistant Secretary of State for Nonproliferation, Robert Einhorn acknowledged positive progress by China in most of the sensitive areas mentioned above. He pointed out that

- China had made a commitment on 11 May 1996 not to provide assistance to unsafeguarded nuclear facilities in Pakistan or anywhere else

- China had agreed to phase out its cooperation with Iran

- China is putting in place for the first time a comprehensive nationwide system of nuclear and nuclear-related dual-use export controls

- China had become a member of the NPT Exporters Committee (the Zangger Committee) in 16 October 1997 , the first time China has joined a multilateral nonproliferation export control regime.

There are expectations that China will in due course also join the Nuclear Suppliers Group set up to establish tighter controls over nuclear transfers than those specified in the NPT. ${ }^{70}$

It might be argued that China has only become sensitive to US concerns because there are sanctions if it does not, such as withholding trade access and blocking exports of high-technology commercial goods, such as communication satellites. The United States can suspend exports of nuclear materials, facilities and components to China unless the President certifies that China has conformed to US nonproliferation policies in accordance with 'Prerequisites for Implementation of the 1985 US-PRCAgreement for Peaceful Nuclear Cooperation'. 
Whatever the reasons may be for China's compliance, as US Deputy Assistant Secretary of State for Nonproliferation, Robert Einhorn stated, the United States was seeing progress beyond mere words, with concrete action in terms of nuclear-related sales to third countries rejected or cancelled, detailed regulations and control lists adopted and publicised and active participation in international regimes initiated.

Einhorn said, however, that the United States wanted to see China make more progress on non-nuclear non-proliferation issues-chemical, missile and advanced conventional arms-where the United States still had serious problems with China's policies and practices. ${ }^{71}$

\section{Conclusions}

In the past, China may have ignored arms control values and sold WMD-related technology for reasons including commercial and diplomatic, keeping Chinese industries in business, accessing technology swaps, gaining strategic advantage or obligations to an ally, as in the case of Pakistan, or it might have been a matter of influence building in zones of importance, such as the Middle East, in deals with Iran, Syria and Algeria. ${ }^{72}$

But the recent record shows that, despite some lapses and a willingness to exploit grey areas, China has, on the whole, been willing and able to uphold its commitments to international arms control regimes.

China wants peace and stability on its borders and in the world generally like any other country with global trading interests, domestic reconstruction priorities and a requirement for stable supplies of key raw materials, such as oil. In this regard, China has geopolitical interests in common with the United States. China also shares with the United States, and the Asia Pacific community, a common interest in stability in the Korean peninsula and avoidance of any excuse that might fuel a Japanese quest to become a 'normal' military power. China has been willing to accept arms control commitments even at some cost to its own narrower self-interest. For example, the freezing of the nuclear weapons technology gap 
that followed China's signing of the CTBT and the loss of revenue and political influence that followed the suspension of missile sales to the Islamic states.

Why? Because it wants to advance its own security through regional and global peace, and that means, by definition, good relations with the United States, the most important country in the world for China in terms of trade, technology, diplomacy and security. In this context, it is not surprising that China has avoided condemning the United States for breaches of the same rules it seeks to apply to China. For example, the United States has exported dual-use technologies to US friends and allies that are banned under MTCR Category I, such as submarine launched Trident ballistic missiles to the United Kingdom; provision of dualuse technology in the equatorial satellite launches of Russia and Norway, and large solid propellant rocket boosters for Japan's space launch vehicle, the $\mathrm{H}-2 \mathrm{~A}$.

China has had an eye on its public image as a credible, law-abiding member of the international community. But, in my view, that is only one consideration and not the primary one. China is driven by a desire to free itself from the distraction of international tension and the risk of conflict. It wants to follow the Japanese model of minimal defence expenditure and conversely it has learned a lesson from the Soviet mistake of over-expenditure on defence. It wants to focus on domestic economic, social and political reconstruction for 'a long period of time'. That entails an appreciation of the benefits of arms control mechanisms in China's near region and globally.

China's behaviour in supporting arms control processes might be attributed to a concern about its global public relations image, realpolitik interests including a mix of commercial advantage, access to advanced technology, reining in the lead of the United States and Russia, securing stable supplies of raw materials, preserving a peaceful world in which to concentrate on its modernisation, and placating its biggest rival and potential enemy in the meantime. Whatever the reason, China's record on arms control is nonetheless primarily one of compliance and broadly shared interests with the United States. In the joint statement issued by 
Presidents Jiang Zemin and Bill Clinton in Washington on 29 October 1997, China and the United States agreed that one of their common interests was to prevent the proliferation of weapons of mass destruction.

When one looks at China's record, it is clear, notwithstanding the views of people like Helms, Milhollin and others, that the Chinese government has been positive and responsive to US concerns and is interested in the same nonproliferation goals as the United States.

Of course, China has problems with the US approach. It is unhappy with what it perceives to be

- the discriminatory provisions in MTCR that do not take account of the concerns of third world countries

- the need to promote the concept of cooperative security rather than unilateralism, confrontation, containment and deterrence

- the need to take steps under the NPT to eliminate WMD, including the US nuclear arsenal

- the need to preserve the Anti-Ballistic Missile (ABM) Treaty by not launching into Theatre Missile Defence (TMD) and National Missile Defence (NMD) systems that might lead to an arms race in outer space

- the transfer of responsibility to the UN Security Council for preventing WMD proliferation issues

Nonetheless, China has joined the game and, on the whole, it plays by the rules.

The most telling statistic I came across in preparing this chapter was from Michael Swaine and Alastair lain Johnston. They point out that in the Maoist period China was negative and dismissive of arms control. In 1970, China had signed about 10 per cent of all arms control agreements that it was eligible to sign. By 1996, this figure had jumped to 90 per cent. ${ }^{73}$

These facts, it was stated in China's first Defence White Paper, demonstrate that 'China is a responsible big country' when it comes to arms control. ${ }^{74}$

This sense of responsibility on China's part may not last long if the United States moves to develop anti-missile defences. China is not a party to the 1972 ABM Treaty but it regards the Treaty as a 
cornerstone of the strategic arms limitation regime and therefore indispensable to maintaining global strategic stability, preventing an arms race in outer space and ensuring gradual nuclear disarmament. China therefore is aghast at the prospect of TMD and NMD systems, especially while the United States preserves its vastly superior strategic arsenal. It is particularly concerned that a US-designed TMD system will cover Taiwan, which China regards as part of 'one China'.

The Clinton Administration has proposed missile defence systems with a capability of hitting warheads travelling at $5 \mathrm{~km} / \mathrm{second}$ with a range of about 3000 kilometre. As 80 per cent of Chinese land-based missiles have a range of 3000 kilometre or less, they would be classified as theatre weapons under the US definition. ${ }^{75}$ If a TMD system is located in NortheastAsia, China's modest nuclear deterrent and leverage vis-à-vis Japan and the United States might be degraded. In China's view, Taiwan's instinct to strike out for independence will inevitably strengthen in such circumstances.

In the absence of some sensitive pre-emptive arms control diplomacy by the United States and credible assurances to China about the aims and limitations of TMD and NMD, China's commitment to arms control processes could quickly evaporate, with increasing pressure on China to modernise and multiply its strategic weapons. This could contribute to a negative spiral in Sino-US relations, a missile and anti-missile arms race, perhaps a new Cold War, and, at the very least, strategic instability in East Asia and the wider Asia Pacific region.

\section{Acknowledgment}

An earlier version of this paper was published in Journal of East Asian Affairs, 14, no.I (Spring/Summer 2000).

\section{Notes}

See testimony, James Lilley, 'Proliferation: Chinese case studies', Hearing before the Subcommittee on International Security, Proliferation and Federal Service, Committee on Governmental Affairs, US Senate, USGPO, Washington, 1997. 
2 On this, see Alastair lain Johnston, 'Learning versus adaptation: explaining change in Chinese arms control policy in the $1980 \mathrm{~s}$ and 1990', China Journal, 35 (January 1996), 27, 39.

3 Michael Swaine and Alastair lain Johnston, 'China and arms control institutions', in E. Economy and M. Oksenberg, China Joins The World Progress and Prospects (New York: Council on Foreign Relations, 1999), 90, 93, 105.

4 Robert ]. Einhorn, Deputy Assistant Secretary of State for Nonproliferation, 'Proliferation: Chinese case studies', Hearing before the Subcommittee on International Security, Proliferation and Federal Service, Committee on Governmental Affairs, US Senate, USGPO, Washington, 1997, 6.

5 Liu Huaqiu, 'No-first-use and China's security', Electronic Essay, The Henry L. Stimson Centre, 5 October 1999. Available online at http://www.stimson.org/pubs/zeronuke/prefnfu.htm.

6 Senior Colonel Zou Yunhua, 'China and the CTBT negotiations', Working Paper, Stanford University, Stanford, 1998.

7 'Beijing envoy lists flaws in nuclear test ban treaty', Xinhua (Domestic service), II September 1996; and Beijing Central Television, 'Qian Qichen signs Comprehensive Test Ban Treaty', 25 September 1996; 'China calls for flexibility in nuclear test ban talks', Reuters, Jakarta, 24 July 1996; 'China makes great concessions, wants early CTBT', Ming Poo, Hong Kong, 14 July 1996.

8 Senior Colonel Zou Yunhua, 'China and the CTBT negotiations', 26. 9 Ibid.

10 See Alastair lain Johnston, 'Learning versus adaptation: explaining change in Chinese arms control policy in the 1980s and 1990', China Journal, 35 (January 1996), 27, 3 I.

1 Zachary S. Davis, 'China's nonproliferation and export control policies', Asian Survey, 35, no.6 (June 1995):587, 592. See also Alastair lain Johnston, 'Learning versus adaptation: explaining change in Chinese arms control policy in the 1980s and 1990', China Journal, 35 (January 1996), 27, 51.

12 State Council, China's National Defence, Defence White Paper, State Council, Beijing, July 1998.

13 Charles N. Van Doren and Rodney Jones, 'China and nuclear nonproliferation: two perspectives', Occasional Paper 3, Program for Promoting Nuclear Nonmproliferation, University of Southampton, 1989, 1, 2.

14 'Pakistan denies import of $\mathrm{N}$-weapon technology from Beijing', Xinhua, Beijing, 29 February 1996. 


\section{Power and Responsibility in Chinese Foreign Policy}

15 Senior Colonel Zou Yunhua, 'Chinese perspectives on the South Asian nuclear tests', Working Paper, Leland Stanford Junior University, January 1999, 12.

16 US Information Agency, 'US-China joint statement on South Asia', USIA Washington File EPF403, Department of State, Washington, DC, 2 July 1998.

17 US Information Agency, 'DAS Susan Shirk worldnet on US-China relations', USIA Washington File EPF502, Department of State, Washington, DC, 21 May 1999.

18 See Jane's Intelligence Review, 'China's missile sales-few changes for the future', Jane's Intelligence Review, 4, no.12 (December 1992), 559.

19 Quoted in 'China helping Algeria build N-reactor: US', The Japan Times, 17 April 1991, 2.

20 Andrew I. Nathan and Robert S. Ross, The Great Wall and the Empty Fortress (New York: Norton and Co, 1997), 75; 'Opening of second stage of heavy water reactor in Algiers', Xinhua, Algiers, 18 January 1994.

21 See Zachary S. Davis, 'China's nonproliferation', 587; and Shirley A. $\mathrm{Kan}$, 'Chinese proliferation of weapons of mass destruction: current policy issues', CRS Issue Brief 92056, Congressional Research Service, Washington DC, 1998, available online at http:/www.fas.org/spp/ starwars/crs/crs92056.htm; accessed I August 2001.

22 See Bingham Kennedy, 'Curbing Chinese missile sales: from imposing to negotiating China's adherence to the MTCR', Journal of Northeast Asion Studies, 15, no.I (Spring 1996), 57-68.

23 US Information Agency, 'US satisfied with China's nuclear controls, US officials say', USIA Washington File EPF508, Department of State, Washington, DC, 31 October 1997.

US Information Agency, 'Lauder says biological weapons threat is growing', USIA Washington File EPF419, Department of State, Washington, DC, 4 March 1999.

25 US Information Agency, McCurry, Berger Sperling 27 June 1998 Briefing', USIA Washington File EPFI07, Department of State, Washington, DC, 29 June 1998.

26 Statement by Sha Zukang, China's Disarmament Ambassador in Geneva, 26 June 1997.

27 Swaine and Johnston, 'China and arms control institutions', 90, 111 .

28 Office of the Secretary of Defense, Proliferation: threat and response (Washington DC: Office of the Secretary of Defense, 1996), 9.

29 Einhorn, Testimony, 16. 

1996.

3 US Information Agency, 'Background briefing on nuclear cooperation', USIA Washington File 404, Department of State, Washington, DC, 30 October 1997.

32 Gary Milhollin, 'Proliferation: Chinese case studies', Testimony to hearing before the Subcommittee on International Security, Proliferation and Federal Service, Committee on Governmental Affairs, US Senate, USGPO, Washington, 1997, 30.

33 Kan, 'Chinese proliferation of WMD'.

34 US Information Agency, 'McCurry, Berger Sperling 27 June 1998 Briefing', USIA Washington File EPFI07, Department of State, Washington, DC, 29 June 1998.

35 US Information Agency, USIA Washington File EPF501, Department of State, Washington, DC, 13 March 1998.

36 State Council, China: arms control and disarmament (Beijing: State Council of the PRC, 1995), 24-25.

37 Swaine and Johnston, 'China and arms control institutions', 118-19.

38 Nazir Kamal, 'China's arms export policy and responses to multilateral restraints', Contemporary South East Asia, 14, no.2 (September 1992), 121.

39 Alexander Downer, 'China's commitment to prevent ballistic missile proliferation welcomed', Media Release of the Australian Minister for Foreign Affairs, 23 November 2001.

40 US Information Agency, 'Republican policy agenda on US China policy', USIA Washington File EPF504, Department of State, Washington, DC, 18 July 1997.

41 Reuters, 20 January 1998, cited in Kan, 'Chinese proliferation of WMD', see also US Information Agency, 'National Security Adviser Sandy Berger, briefing on Clinton trip to China', USIA Washington File EPF303, Department of State, Washington, DC, 17 June 1998.

42 China has agreed 'to actively study joining the MTCR'. US Information Agency, 'McCurry, Berger Sperling 27 June 1998 Briefing', USIA Washington File EPFI07, Department of State, Washington, DC, 29 June 1998.

43 Swaine and Johnston, 'China and arms control institutions', 113.

44 See R. Bates Gill, 'Curbing Beiling's arms sales', Orbis, 36, no.3 (Summer 1992), 379, 386.

45 Senior Colonel Zou Yunhua, 'Chinese perspectives on the South Asian nuclear tests', Working Paper, Leland Stanford Junior University, Stanford, 1999, 13. 


\section{Power and Responsibility in Chinese Foreign Policy}

Milhollin, Testimony, 29.

'Report cites China-Pakistan missile links', The Washington Post, 13 June 1996.

'China denies aiding Pakistan missile plant', Reuters, 26 August 1996.

See US Information Agency, 'Helms demands US sanction China for missile proliferation', USIA Washington File EPR507, Department of State, Washington, DC, 17 September 1999; see also US Information Agency, 'New CIA report assesses future ballistic missile threat', USIA Washington File EPF507, Department of State, Washington, DC, 19 September 1999; and Kan, 'Chinese proliferation of WMD'.

Senior Colonel Zou Yunhua, 'Chinese perspectives on the South Asian nuclear tests', 12.

'China sends nuclear power plant equipment to Pakistan', Xinhua, Shanghai, 7 February 1996.

Robert J Einhorn, Deputy Assistant Secretary of State for Nonproliferation, Department of State 'Proliferation: Chinese case studies', Hearing before the Subcommittee on International Security, Proliferation and Federal Service, Committee on Governmental Affairs, US Senate, USGPO, Washington, 1997, p.3, 4.

Davis, 587.

Einhorn Testimony, 13, 18.

'US says no sanctions on China in nuclear dispute', Reuters, Washington, II May 1996.

See Kennedy, 'Curbing Chinese missile sales'.

'Beijing flouts nuke-sales ban', The Washington Times, 9 October 1996, 1.

The Washington Times, 10 October 1996; and 'US says China did not violate nuclear pledge', Reuters, 10 October 1996.

'Foreign Minister Tang Jiaxuan: investigations clear PRC firms of involvement in Iraqi air defence upgrades', Xinhua, Beijing, 6 March 2001.

Mitchel B. Wallerstein 'China and proliferation: a path not taken', Survival, 38, no.3 (Autumn 1996), 58, 59.

In this context, see Kan, 'Chinese proliferation of WMD'.

Milhollin, Testimony, 30.

Cited in Kan, 'Chinese proliferation of WMD'.

US Information Agency, 'Helsm/Shelby Letter on US-China nuclear agreement', USIA Washington File EPF204, Department of State, Washington, DC, 28 October 1997. 


\section{china and arms control: a learning process}

65 Select Committee, US House of Representatives, US National Security and Military Commercial Concerns with the PRC [The Cox Report] (Washington DC: US House of Representatives, 1999), xxxvii, 78, 198.

66 Cited in Kan, 'Chinese proliferation of WMD'.

67 Milhollin, Testimony.

68 US Information Agency, 'Albright/Berger briefing', USIA Washington File EPF305, Department of State, Washington, DC, 29 October 1997.

69 US Information Agency, 'Fact sheet: accomplishments of US-China summit', USIA Washington File EPF307, Department of State, Washington, DC, 29 October 1997.

70 According to remarks attributed to Bates Gill in Swaine and Johnston, 'China and arms control institutions', 90.

7 US Information Agency, 'Einhorn statement on nuclear cooperation with China', USIA Washington File EPF308, Department of State, Washington, DC, 4 February 1998.

72 For a discussion see Karl W. Eikenberry, 'Explaining and influencing Chinese arms transfers', Paper Number 36, National Defense University, Washington DC, 1995.

73 Swaine and Johnston, 'China and arms control institutions', 90, $100-1$.

74 China's National Defence, State Council, Beijing, July 1998.

75 Alastair lain Johnston, 'China's nuclear forces: doctrine, modernisation and arms control', conference paper presented in Hong Kong, 1315 July 1995. 